\title{
CCND1 Gene Amplification
}

National Cancer Institute

\section{Source}

National Cancer Institute. CCND1 Gene Amplification. NCI Thesaurus. Code C36652.

A molecular genetic abnormality indicating the presence of multiple copies of the CCND1 gene. 